\title{
PROJETO BANCO DE DADOS SOBRE COMUNICAÇÃO MUSEOLÓGICA
}

O Serviço de Museologia do MAE/USP tem a responsabilidade de estabelecer, implementar e sistematizar os experimentos museológicos, vinculados à estruturação de um processo de comunicação que ao mesmo tempo colabore para a divulgação das pesquisas realizadas pelas Divisões de Arqueologia e Etnologia, atue como agente decisivo para a extroversão dos diversos segmentos do acervo e, mais ainda, contribua de maneira sistemática para a instituição desempenhar seu papel educacional.

Para tanto, foi elaborado um programa Técnico-Científico estruturado no desenvolvimento de linhas de pesquisa museológica (Musealização e Avaliação) e em projetos ligados à Formação Profissional e Estudos Bibliográficos.

A base para estas investigações está centrada no desenvolvimento do Projeto Banco de Dados sobre Comunicação Museológica.

Trata-se da sistematização e armazenamento da memória referente às exposições temporárias, no que diz respeito aos temas escolhidos e aos respectivos enfoques conceituais ligados à Arqueologia e Etnologia que embasam as propostas museológicas. Da mesma forma serão preservados os documentos referentes às diferentes montagens, tais como planta-baixa, mobiliário e linguagem de apoio.

A avaliação de cada experimento é parte significativa da construção deste Banco de Dados, na medida em que indicará os caminhos para a comunicação museológica sistemática, procurando cada vez mais aprimorar os enfoques temáticos em relação às expectativas do público.

Este projeto teve seu início, em 1991, marcado pelo levantamento realizado pelo Serviço de Museologia junto aos arqueólogos e etnólogos sobre os principais temas a serem musealizados. Em seguida, foi realizado um primeiro estudo visando à organização de um cronograma de exposições que estivesse, em um primeiro momento, vinculado aos compromissos dos projetos institucionais, tais como organização de cursos, publicação de livros ou mesmo a organização de eventos científicos e, em um segundo momento, o agendamento das exposições deveria seguir a proposta museológica institucional que procurará fazer das mostras temporárias projetos museológicos mais detalhados do ponto de vista da comunicação da pesquisa científica.

A partir do início de 1992 tem sido possivel realizar os experimentos museológicos previstos neste projeto e desta forma alimentar o Banco de Dados com elementos conceituais, a respectiva documentação museográfica e as informações avaliatórias. As exposições temporárias "Plumária Indígena Brasileira", "Encontro de Culturas no Mediterrâneo Antigo", "Os Projetos de Arqueologia do MAE" e "A Escrita do Mundo Antigo", se por um lado correspondem a eventos institucionais do MAE/USP, por outro lado têm sido objeto de pesquisa museológica e têm contribuído para a organização deste Banco de Dados.

Estas experimentações serão complementadas com levantamento bibliográfico sobre exposiç̃̃es dessa natureza.

A concep̧̧ão desse projeto e/ou seu desenvolvimento estão sustentados na elaboração e preenchimento de fichas de trabalho, que darão a base para a informatização dos dados e imagens correspondentes.

Cabe ressaltar que o Projeto Banco de Dados sobre Comunicação Museológica tem dois objetivos principais, a saber:

$1^{\circ}$. criar as bases para o desenvolvimento de pesquisa de natureza museológica $e$;

$2^{\circ}$. desenvolver a pesquisa museológica a partir de metodologia que permita a necessária interdisciplinaridade dos museus.

\section{Maria Cristina Oliveira Bruno *}

Recebido para publicação em 30 de junho de 1993.

${ }^{*}$ ) Museu de Arqueologia e Etnologia da Universidade de São Paulo. 